\title{
NEW COMPOUND N1,N1'-(2"-BROMO-2"-CHLOROETHENYL)-BIS-(5- FLUOROURACIL) AS THE ACTIVE ANTITUMOR AGENT FOR SARCOMA 180
}

\author{
Elena Welchinska ${ }^{1}$, Valeriia Vilchynska ${ }^{2}$
}

\begin{abstract}
The problem of how to treat malignant tumors and the search for effective low-toxic anticancer drugs are among the most important in modern medicine and other chemical and biological sciences, including pharmaceutical chemistry. The arsenal of anticancer drugs occupies a prominent position as medications related to heterocyclic systems (cancer of the digestive system and other areas). In this regard, further development towards new derivatives of purine and pyrimidine series are of significant scientific interest and justify the relevance, novelty, and scientific practical significance of this study. Synthesis of 5-fluorouracil bis-derivative was performed with a halogen-containing pharmacophore group to compose a molecule that was studied for its physical, chemical, and biological properties. Synthesis of 5-fluorouracil bis-derivative is a typical example of substitution reactions with a heteroatom of the uracil molecule (N1) as the second component in the reaction involving halothane, a known inhaled anesthetic. The reaction was carried out in a solvent system of benzenedimethylformamide-diethyl ether, under conditions of phase transfer catalysis with dibenzo-18-crown-6 (DB 18C6) complex (alkaline medium), by heating ( $14 \mathrm{~h}$ ), followed by purification, and drying of the products. The structure of the synthesized compound was confirmed by elemental analysis, infrared, and proton nuclear magnetic resonance $\left({ }^{1} \mathrm{H} \mathrm{NMR}\right)$ spectroscopy. By varying the reaction conditions, a synthesized compound of high purity was obtained with increased practical output of up to 50\%. The toxicity and antitumor activity of the synthesized compound were investigated. The new substance, 5-fluorouracil bis-derivative, was found to have high antitumor activity, reducing the Sarcoma 180 tumor by $51.7 \%$ (activity criterion $\geq 50 \%$ ). This suggests the synthesized compound is suitable as a physiologically active treatment and its further study as a potential vehicle for anti-tumor treatment in patients is recommended.
\end{abstract}

UDC Classification: 547.431.4 - 547.854.4; 547.96 DOI: http://dx.doi.org/10.12955/cbup.v4.842

Keywords: 5-fluorouracil, halothane, sarcoma, toxicity, bis-derivative.

\section{Introduction}

An important prerequisite for the development of methods for the synthesis and reactions of heterocyclic compounds is to gain new knowledge about existing methods of synthesis and their reactivity of their analogies. Introducing organic synthesis as fluorine-containing synthons, such as in fluorocarbon anesthetics, was one of the most important achievements regarding organofluorine chemical compounds. They are volatile, non-flammable, and moderately toxic. Most have only one molecule of carbon-hydrogen $(\mathrm{CH})$ fragment. The relationship between the narcotic effect of such compounds, their hydrophobic properties, and the ability to associate is described in the literature (Blohin, \& Perevodchikova, 1984; Isikava, 1990; Filler, Kobayashi, \& Yagupolskiy, 1993; Alonso, Shaw, \& Wright, 1984). Synthesis, which uses similar fluorine-containing synthons, is referred to as 'soft chemistry of fluoride'. On the other hand, in the reactions heterocycles of pyrimidine series are used. First, the reactions of the fluorine-containing synthons are used to study the behavior of uracil (Zavialov, Esov, \& Kravchenko, 2003). The new preparative method for the synthesis of the original bis-derivative of 5-fluorouracil with a pharmacophore group $(-\mathrm{C}=\mathrm{CBrCl})$ where the fluorinecontaining synthon as a usable reagent is a well-proven and available anesthetic, 2-bromo-2-chloro1,1,1-trifluoroethane (halothane), and yielded a compound with potential anticancer activity. This marked attention to transforming the fluorine-containing fragments into new molecules involves strengthening of anti-metabolic properties of the compounds. Such input of pharmacophore groups in aliphatic structure chains and aromatic rings using halothane for the synthesis of biologically active compounds with the polyfluoroalkoxy groups are described in literature (Gerus, Kolicheva, \& Yagupolskiy, 1989; Yagupolskiy, 1988). For the first time, in a single experimental setting, the antitumor activity of the selected compound was studied in vivo and in vitro in cancer cells of Sarcoma 180. As a result, an agent with a significant antitumor effect was discovered. Furthermore, the conditions of the reaction were defined, the methods developed, and the composition of the reaction product studied. The studies revealed that the initial heterocycle, 5-fluorouracil reacts with the intermediate product of halothane (I); undergoes conversion in an alkaline medium under conditions of

\footnotetext{
${ }^{1}$ Elena Welchinska, Pharmaceutical Faculty, Bohomolets National Medical University, Kiev, Ukraine, elena_wwu@ukr.net

2 Valeriia Vilchynska, Bohomolets National Medical University, Kiev, Ukraine
} 
phase transfer catalysis dibenzo-18-crown-6 (DB 18C6) complex in a solvent system of benzenedimethylformamide-diethyl ether (benzene-DMFA-diethyl ether) or in another variant (II); and in dimethyl sulfoxide (DMSO) in the presence of anhydrous potassium carbonate forms bis-derivative of 5-fluorouracil (III). These reactions enabled the development of a new strategy for the synthesis of selective poly-functionalized molecules, which has chemical structures available for incorporating new pharmacophore fragments into the molecule (Welchinskaya, Kuzmenko, \& Ilchenko, 1997). To expand the list of convenient and chemically available reagents for introducing fluorinated substituents into the heterocyclic molecules, the authors modified the above-described synthesis methods, and, as a result, a new compound was synthesized: - N1,N1'-(2"-bromo-2"-chloroethenyl)-bis-(5-fluorouracil). The above chemical reactions are shown in Figure 1.

Figure 1: Synthesis of new compound N1,N1'-(2"-bromo-2"-chloroethenyl)-bis-(5-fluorouracil) (III) with pharmacophore group, $=\mathrm{C}=\mathrm{CBrCl}$

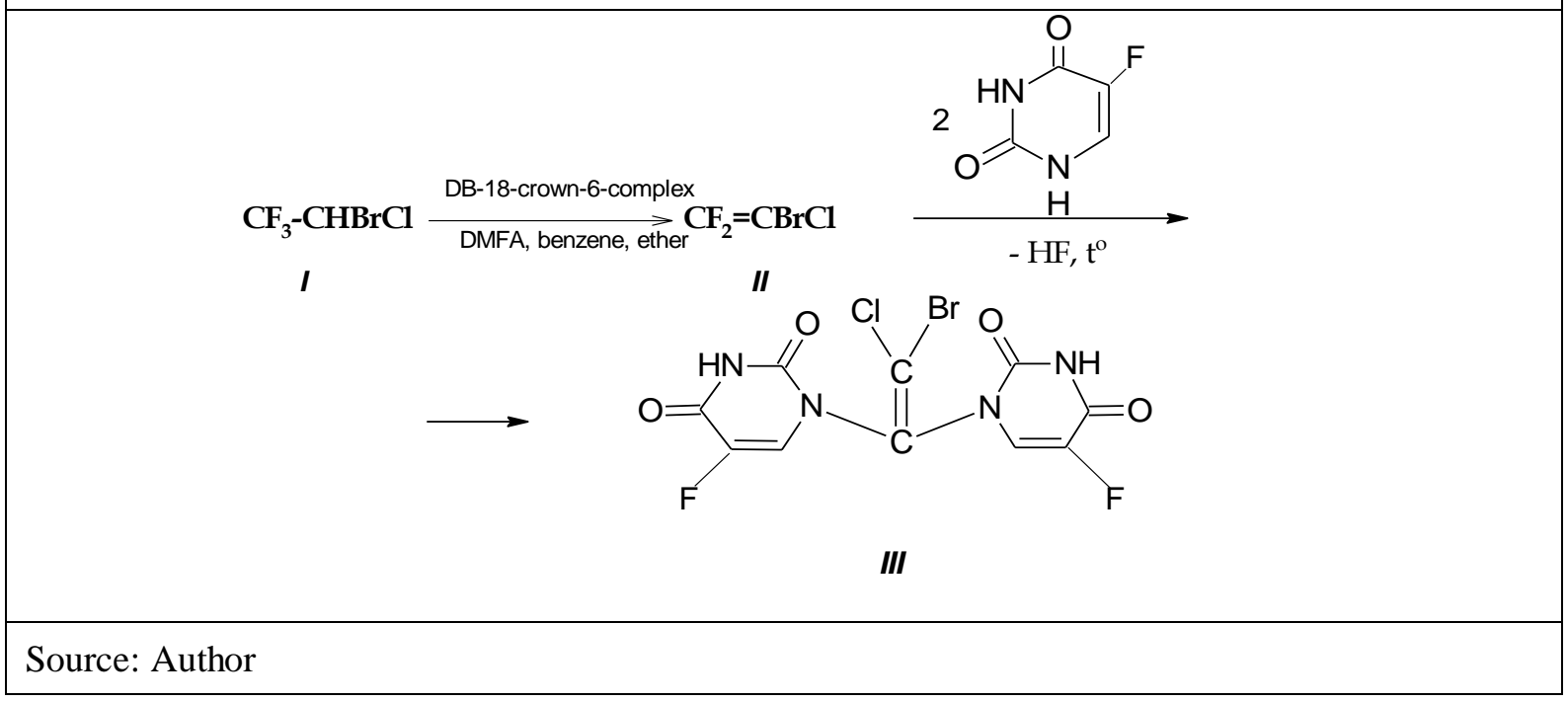

This study tests the new compound (Figure 1, III) on cancer cells of Sarcoma 180.

\section{Methods}

The majority of the absolute organic solvents (benzene, dimethylformamide (DMFA), hexane, and ethylether) employed in this study were distilled before their use. The organic solvents were dried over anhydrous magnesium sulfate or metallic sodium. Gas-liquid chromatography was carried out using a Perkin Elmer chromatograph with UV-detector ('Perkin', Germany). The infrared (IR) spectra were recorded with a UR-20 spectrometer ('Charles Ceise Hena', Germany). The proton nuclear magnetic resonance (1H NMR) spectra were recorded in DMSO-d6 on a 200-MHz BrakerWP-200 ('Braker', Switzerland) or a Varian T-60 spectrometer ('Varian', USA). The Compound III is a crystalline precipitate with a cream color; unstable during recrystallization at high temperatures; and reverts to uracil with boiling. Thus, to clean it, the precipitate was washed with a mixture of diethyl ether-hexane (1:1), then dried in a water-jet pump. New compounds with significant antitumor activity have been selected and investigated (Prozorovskiy, Prozorovskiy, \& Demchenko 1978; Sophyina, Sophyina, Goldin, \& Kmein, 1979, Stefanov, 2001). White inbred biomedical mice and rats (300 animals) and the experimental model of tumor for Sarcoma 180 were used, following published procedures (Prozorovskiy et al., 1978; Sophyina et al., 1979). The experimental tumor used in our investigation was obtained from the Strain Bank of the Cancer Centre, in the Russian Academy of Medical Sciences. The experimental tumor was used on the experimental animals, subjected to program freezing, and then, preserved at the Strain Bank, Institute of Pharmacology and Toxicology of the National Academy of Medical Sciences, Ukraine. The efficiency parameter, rate of reduction in tumor growth, as volume and mass, was $\geq 50 \%$. The results were assessed by standard methods of statistical analysis (Prozorovskiy et al., 1978; Sophyina et al., 1979). Investigation of critical toxicity of the new compounds was carried out at the Institute of Pharmacology and Toxicology of National Academy, Medical Sciences, Ukraine. The tumor was introduced into the peritoneum. 


\section{Chemistry and Antitumor Activity of Derivative Obtained on the Base of 5-Fluorouracil}

In preparation of $\mathrm{N} 1, \mathrm{~N} 11^{\prime}$-(2"-bromo-2"-chloroethenyl)-bis-(5-fluorouracil) (III), a mixture of potassium hydroxide $(0.44 \mathrm{~g}, 0.0079 \mathrm{~mol})$ and dibenzo-18-crown-6-complex $(0.044 \mathrm{~g}, 0.0079 \mathrm{~mol})$ in $20 \mathrm{ml}$ of dry benzene was heated under reflux at 60 to $80^{\circ} \mathrm{C}$ for $15 \mathrm{~min}$ (Solution 1). The cooled solution was mixed with halothane $(1.57 \mathrm{~g}, 0.84 \mathrm{ml}, 0.0079 \mathrm{~mol})$ in $20 \mathrm{ml}$ of dry ethyl ester. Solution 1 was heated under reflux at 60 to $80^{\circ} \mathrm{C}$ for $15 \mathrm{~min}$. The cooled solution was then mixed with 5-fluorouracil (1.11 g, $0.0079 \mathrm{~mol}$ ) in $40 \mathrm{ml}$ of dry DMFA (Solution 2) and then heated under reflux at 80 to $90^{\circ} \mathrm{C}$ for $14 \mathrm{~h}$. The heated solution was filtered. The precipitate was washed with $20 \mathrm{ml}$ of methyl alcohol anhydrous, $10 \mathrm{ml}$ ethyl ester, and then dried under vacuum. The bis-derivative III was a cream-colored solid (50\%) with melting point of $238-240{ }^{\circ} \mathrm{C}$, with found $\%$ of $\mathrm{N}$ : 13.99 , $\mathrm{C}_{10} \mathrm{H}_{4} \mathrm{BrF}_{2} \mathrm{ClN}_{4} \mathrm{O}_{4}$, calculated \% of $\mathrm{N}: 14.09 ; \gamma_{\max }(\mathrm{KBr})$ of $510,550,690,1150,1210 ; 1735$, and 1750 $\mathrm{cm}^{-1}$; and $\sigma \mathrm{H}$ of $4.53\left(2 \mathrm{H}, 2 \mathrm{~N}_{3} \mathrm{H}\right)$, and $7.45\left(2 \mathrm{H}, 2 \mathrm{C}_{6} \mathrm{H}\right)$.

In all groups, the isolated males of inbred medical mice were provided with standard food rations for the same control. The quantity of animals in each group was six, while the quantity of animals for the experiment was 300 . The minimum weight of the mice body was $17.0 \pm 2.0 \mathrm{~g}$. The age of the mice was two to three months. The percentage of primary recovery and destruction was ' 0 '. The method of euthanizing was decapitation, and ethyl ester overdose. The method for removing the experimental tumors was surgical. The efficiency parameter was the percentage of growth reduction in the tumor (volume and weight), as described by Sophyina et al. (1979), and estimated as follows:

$$
\frac{\text { average tumor growth in control - average growth in experimental group }}{\text { average growth in control group }} \times 100
$$

There were six introductions of the physiological solutions of bis-derivative III each day. The dosage of the preparations corresponded to $1 / 4$ to $1 / 6$ the lethal dose $\left(\mathrm{LD}_{50}\right)$. Results were calculated $24 \mathrm{~h}$ after ending treatment. The main control data were the average weight of the tumor in the control animals $(\mathrm{g})$; average weight of the tumor in the experimental animals $(\mathrm{g})$; percentage of growth reduction of the tumor; index of effectiveness; and spleen ratio. The critical criterion was $>50.0 \%$ of growth reduction in the tumor. The standard for 5-flurouracil (5-FU) was prepared. The express method of defining $\mathrm{LD}_{50}$ was used (Prozorovskiy et al., 1978). Results were calculated using an alternative formula two weeks after the introductions. Statistical analysis was carried out, similar to Perevodchikova (2005). The dose of substance was $30 \mathrm{mg} / \mathrm{kg}$. The mass of cancer was $1.07 \pm 0.09 \mathrm{~g}$. Emesis was observed in experimental animals.

\section{Results and Discussions}

The study results revealed bis-derivative III was more toxic (three times) than the prepared control 5$\mathrm{FU}\left(\mathrm{LD}_{50} 375 \mathrm{mg} / \mathrm{kg}\right)$. Table 1 shows the data for the toxicity of the bis-derivative III.

Table 1: Parameters of toxicity of bis-derivative (III), compared with 5-flurouracil (5-FU)

\begin{tabular}{|l|l|c|}
\hline No. & \multicolumn{1}{|c|}{ Adduct } & $\begin{array}{c}\mathrm{LD}_{50} \\
(\mathrm{mg} / \mathrm{kg})\end{array}$ \\
\hline 1 & N1,N1'-(2"'-bromo-2"-chloroethenyl)-bis-(5-fluorouracil)(III) & 125 \\
\hline 2 & 5-FU (control) & 375 \\
\hline
\end{tabular}

In addition, the results showed that N1,N1'-(2"-bromo-2"-chloroethenyl)-bis-(5-fluorouracil) (III) displayed antitumor activity. After treatment by the bis-derivative III, the weight of the cancer, Sarcoma 180, reduced from $1.070+0.090 \mathrm{mg}$ to $0.516+0.090 \mathrm{mg}$. This showed approximately $51.7 \%$ reduction of the cancer (critical criterion was $\geq 50.0 \%$ of reduction of tumor's growth). This was 1.2 times the standard criterion shown during the treatment of cancer by the morphological control. 


\section{Conclusion}

For the first time, the compound N1,N1'-(2"-bromo-2"-chloroethenyl)-bis-(5-fluorouracil) (III) was synthesized by reaction of 5-fluorouracil with 2-bromo-2-chloro-1,1,1-trifluoroethane (halothane). Synthesis was carried out under phase transfer catalysis with DB-18-crown-6-complex (at the alkali medium). Varying the reaction conditions provided the Compound III of high purity and increased the practical output by up to 50\%. The synthesized compound, bis-derivative of 5-fluorouracil (III), was biologically active. The testing of its toxicity and antitumor activity showed an LD50 for the Compound III of $125 \mathrm{mg} / \mathrm{kg}$, which indicated its higher toxicity as compared with the 5-FU (control). However, Compound III refers to moderately toxic substances. Antitumor activity of the Compound III was studied, for the first time, in cancer, Sarcoma 180. Positive results were obtained with the percentage of inhibition of cancer cells in treating the tumor, Sarcoma 180, by the new Compound III reaching $51.7 \%$ (activity criterion $>50 \%$ ). Therefore, a deeper study of the antitumor activity of the new bis-derivative of 5-fluorouracil (III) on other strains of tumors, for possible positive results are recommended, with further development of the Compound III showing promise as a new anticancer drugs.

\section{References}

Alonso, R., Shaw, G. \& Wright, D. (1984). Thermal addition of heterocycles to bicyclic reagents. Jornal Chemical Society Perkin Translation, I (12), p. 2795-2799.

Blohin, N. N. \& Perevodchikova, N. I. (1984). Himioterapia opyholevih zabolevaniy [Chemical therapy of cancer illness]. (p. 15-82). Moscow, Russia: Medicine.

Isikava, N. (Eds.) (1990). Soedineniy ftora. Syntez i primenenie [Compoundse of fluorine. Synthesis and use]. (p.183-300). Moscow, Russia: Mir.

Filler, R., Kobayashi, Y. \& Yagupolskiy, L. M. (1993). Organo fluorine compounds in medical chemistry and biomedical applications. (p. 200-380). Amsterdam: Elsevier.

Gerus, I. I., Kolicheva, M. T. \& Yagupolskiy, L. M. (1989). 1-Alkoksy(ariloksy)-1,1-diftor-2-hlor-2-brometany [1Alkoxy(aryloxy)-1,1-difluoro-2-chloro-2-bromoethanes]. J. Org. Chem. (Moscow, Russia), Vol.25 (9), p.2020-2021.

Perevodchikova, N. I. (Ed.) (2005). Chimioterapia rakovih zabolevaniy [Chemotherapy of cancerous diseases] (2 ${ }^{\text {nd }}$ edition) (p. 34-87). Moscow, Russia: Practical medicine.

Prozorovskiy, V. B., Prozorovskiy, V. P., \& Demchenko, V. M. (1978). Ekspress-metod opredeleniya sredney effektivnosty dozy i ego oshibka [Express - method of middle effective dose determination and its mistake]. Pharmacology and toxicology, Vol. 41 (4), p. 407-509.

Sophyina, Z. P., Sophyina, A. B., Goldin, A. \& Kmein, A. (Eds.) (1979). Eksperimentalnaya otsenka protivoopuholevyh preparatov v SSSR i SShA [The experimental value of the antitumor drugs in USSR and USA]. (p. 43-67). Moscow, Russia: Medicine.

Stefanov, O.V. (Eds.). (2001). Doklinichni doslidzhenny likarskih zasobiv [Preclinical investigations of the medications]. (p. 125-527). Kiev, Ukraine: Avicenna.

Welchinskaya, H., Kuzmenko, I. \& Ilchenko, A. (1997). Geterotsikliceskie soedineniya s farmakofornimy galogenzameshenimy grupamy [Heterocyclic compounds with pharmacophore halogensubstituted groups]. J. Heterocycl. Chem., 7, p. 967-971.

Yagupolskiy, L. M. (1988). Aromaticheskie I geterocyklicheskie soedineniya s ftorsoderjashimy zamestitelyamy [Aromatic and heterocyclic compounds with fluorocontaining substitutes]. (p. 90-105). Kiev, Ukraine: Naukova dumka.

Zavialov, S. I., Esov, G. I., \& Kravchenko, N. I. (2003). Prirodnie yracili: metody sinteza i khimicheskie svoistva (obzor) [Nature uraciles: symthesis methods and chemical properties (review)]. Chemical-pharmaceutical journal, Vol. 37 (7), p. 3-6. 